\title{
UNIVERSITY OF TWENTE.
}

\section{SOME OBSERVATIONS ON GOVERNANCE AND GOVERNING FOR RESILIENCE}

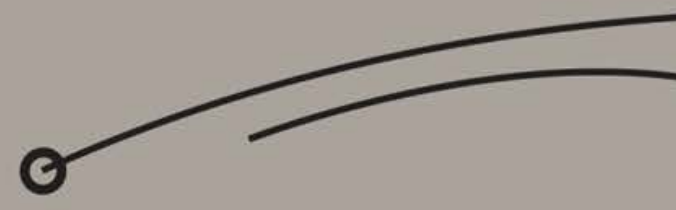

RISTD SLIUZAS

NANEERATIONAL WORKSHOP: RESILIENCE JUST DO IT?!

F GOVERNING FOR RESILIENCE IN VULNERABLE PLACES

COASTAL RESILIENCE RESEARCH GROUP, RUG

FACULTY OF GEO-INFORMATION SCIENCE AND EARTH OBSERVATION 


\section{INTRODUCTION}

- Who am I

- Scope of this presentation: How to govern for resilience?

- Governance and governing - work of Jan Kooiman (em Prof. Erasmus University)

- Resilience - what is it (Simin Davoudi and others) and how is it related to the notion of governing

- Examples

- Kick off for discussions 


\section{GOVERNANCE AND GOVERNING}

- Rakodi 2003, Stoker, 1998

- To govern: steer, guide, control, regulate, influence or determine. What the state does to administer its affairs.

- Governance: interactive relationship between and within government and non-government actors.

- Kooiman (2003, p4)

- Governing: the totality of interactions, in which public as well as private actors participate, aimed at solving societal problems or creating societal opportunities; attending to the institutions as contexts for these governing actions; and establishing a normative foundation for all those activities.

- Governance: the totality if theoretical conceptions on governing. 


\section{INTEGRATED FRAMEWORK FOR GOVERNABILITY OF A SOCIETAL SYSTEM}

KOOIMAN ET AL, 2008, P4.

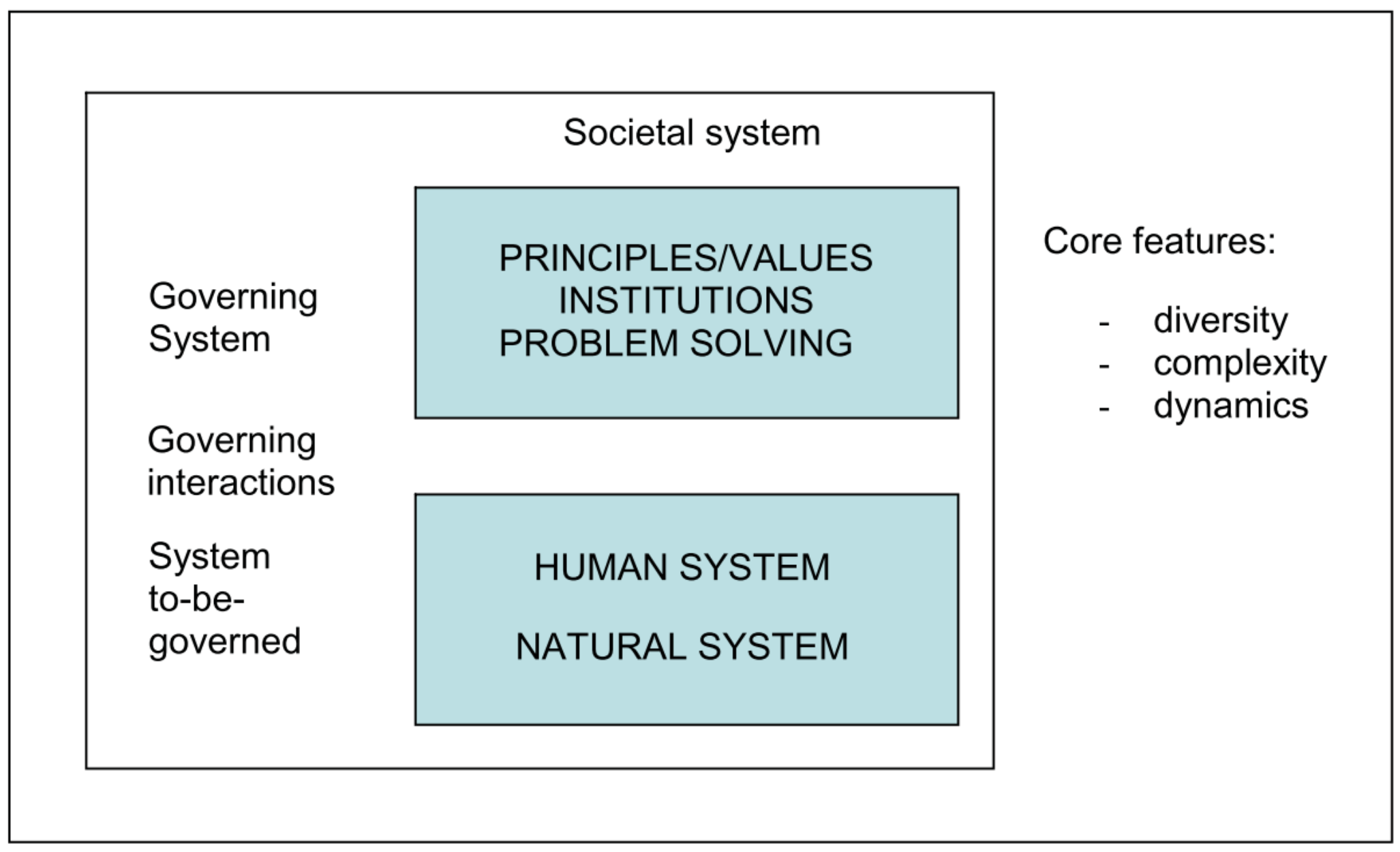




\section{INTERACTIVE GOVERNANCE MODEL}

KOOIMAN ET AL, 2008, P6

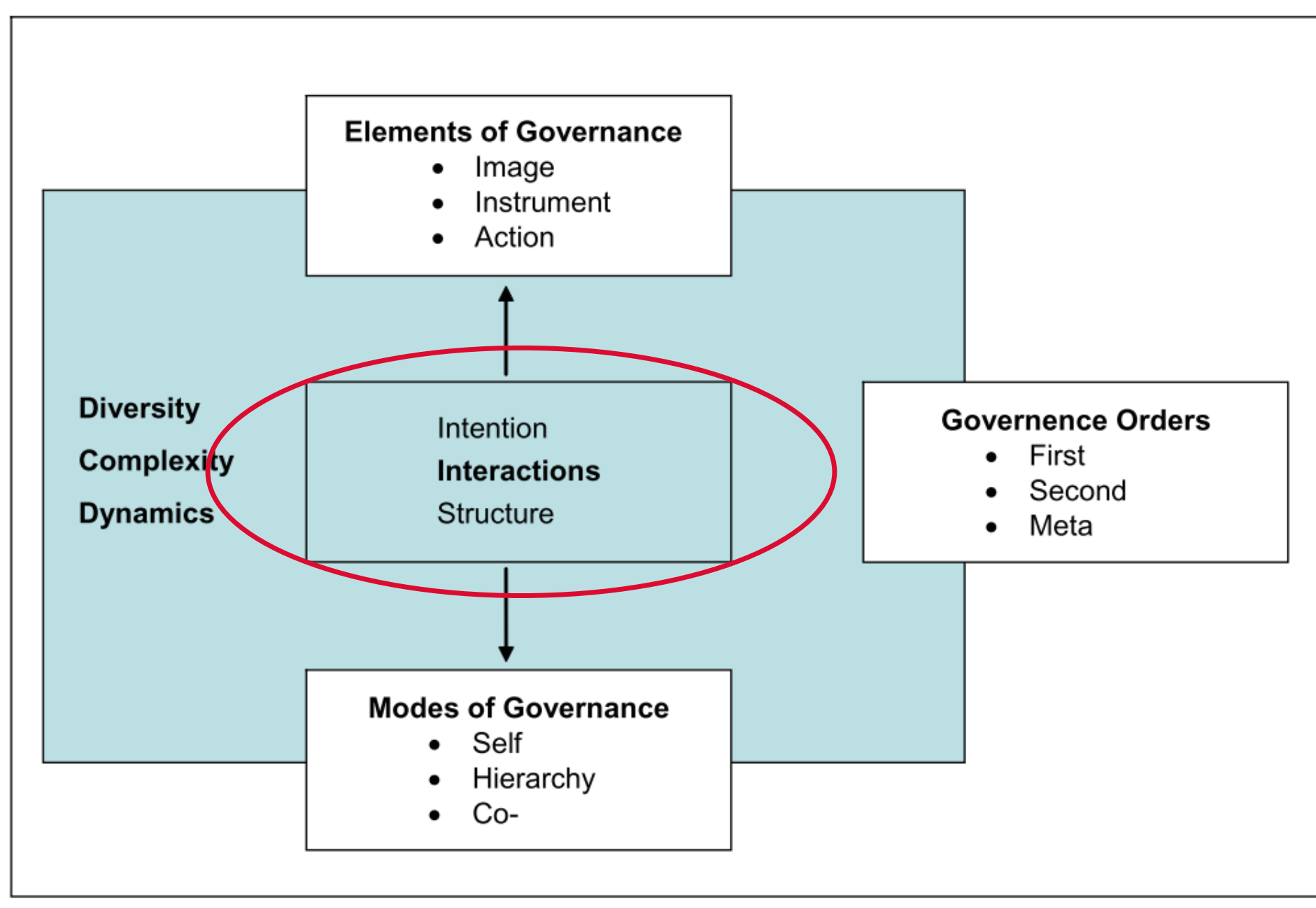




\section{RESILIENCE: A POWERFUL BUT ELUSIVE CONCEPT}

DAVOUDI, 2012; HOLLING.

Engineering: ability of a system to return to an equilibrium or steady state after a disturbance. Return time, efficiency, predictability key issues.

Ecological: the magnitude of the disturbance that can be absorbed before the system changes its structure - ability to persist and critical thresholds notion of regime shifts. Multiple equilibria are possible.

From bouncing back to bouncing forward

Evolutionary resilience: ability of complex socio-ecological systems to change, adapt, and crucially, transform in response to stresses and strains (Carpenter et al) 


\section{FOUR CRITICAL ISSUES}

DAVOUDI, 2012

1. Human inventiveness is not well incorporated - innovation, ingenuity etc can lead to transformations. Ideological high-jacking of the term to value self-reliance of communities as a justification for pulling back the role of the state.

2. Resilience to what ends? What is the ultimate goal and can we measure the current and future status reliably?

3. System's boundary. Which elements are considered to make up the system (inevitably the system model must be simplified)? Possibility for exclusionary practices. Spatial exclusion could also play a role.

4. Power and politics: what is a desirable outcome and for whom? 


\section{CAPACITIES FOR STRENGTHENING RESILIENCE OECD, 2014.}

Figure 3: The relationship between absorptive, adaptive and transformative capacities for strengthening resilience

\begin{tabular}{|c|c|c|}
\hline \multicolumn{3}{|c|}{ Intensity of change / transaction costs } \\
\hline stability & flexibility & change \\
\hline Absorptive coping & Adaptive & Transformative \\
\hline capacity & Capacity & Capacity \\
\hline (persistence) & (incremental adjustment) & (transformational responses) \\
\hline
\end{tabular}

Source: Béné et al (2012) 


\section{INTEGRATED FRAMEWORK FOR GOVERNABILITY OF A RESILIENT SOCIETAL SYSTEM}

KOOIMAN ET AL, 2008, P4.

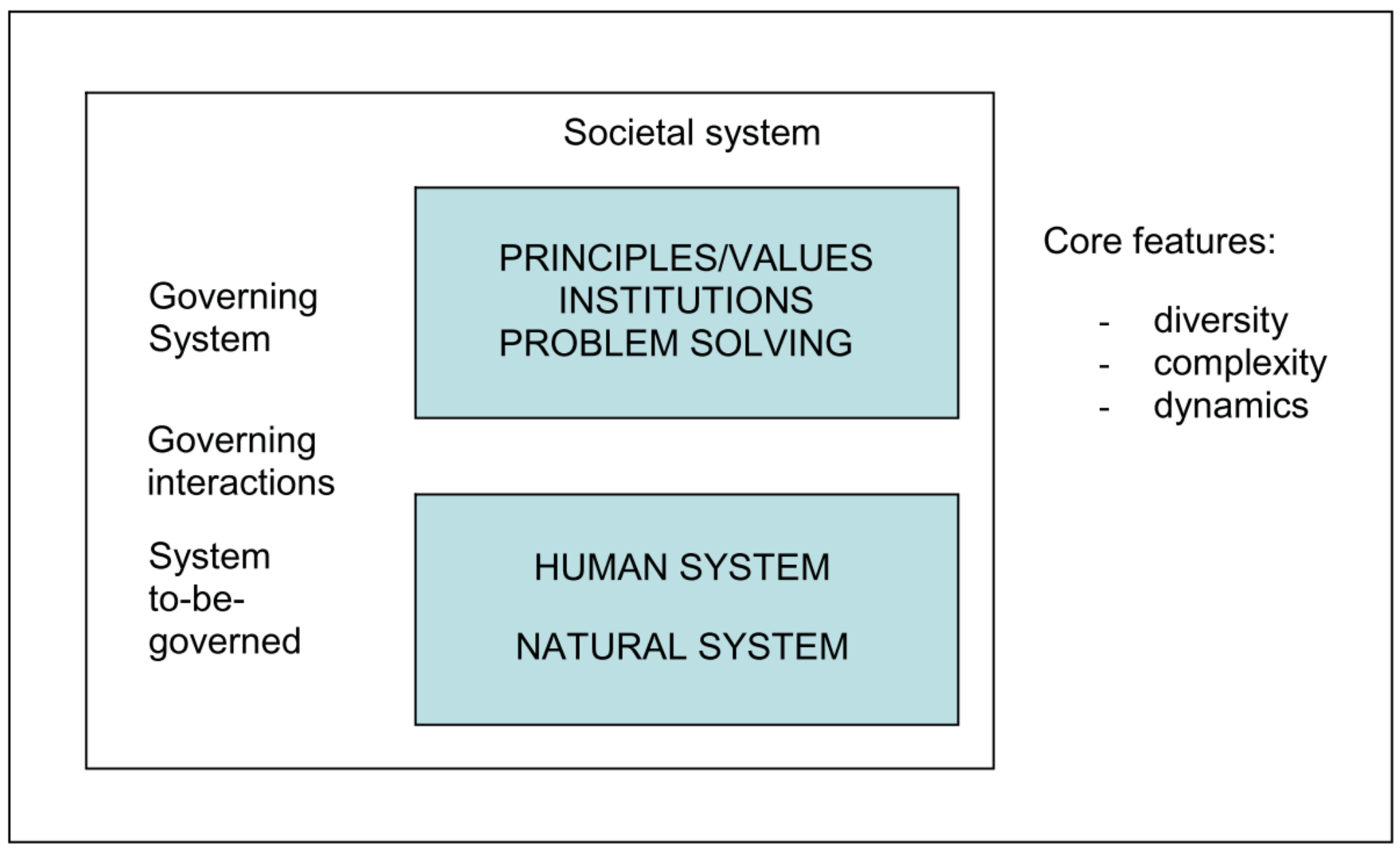




\section{RESILIENCE SYSTEMS ANALYSIS}

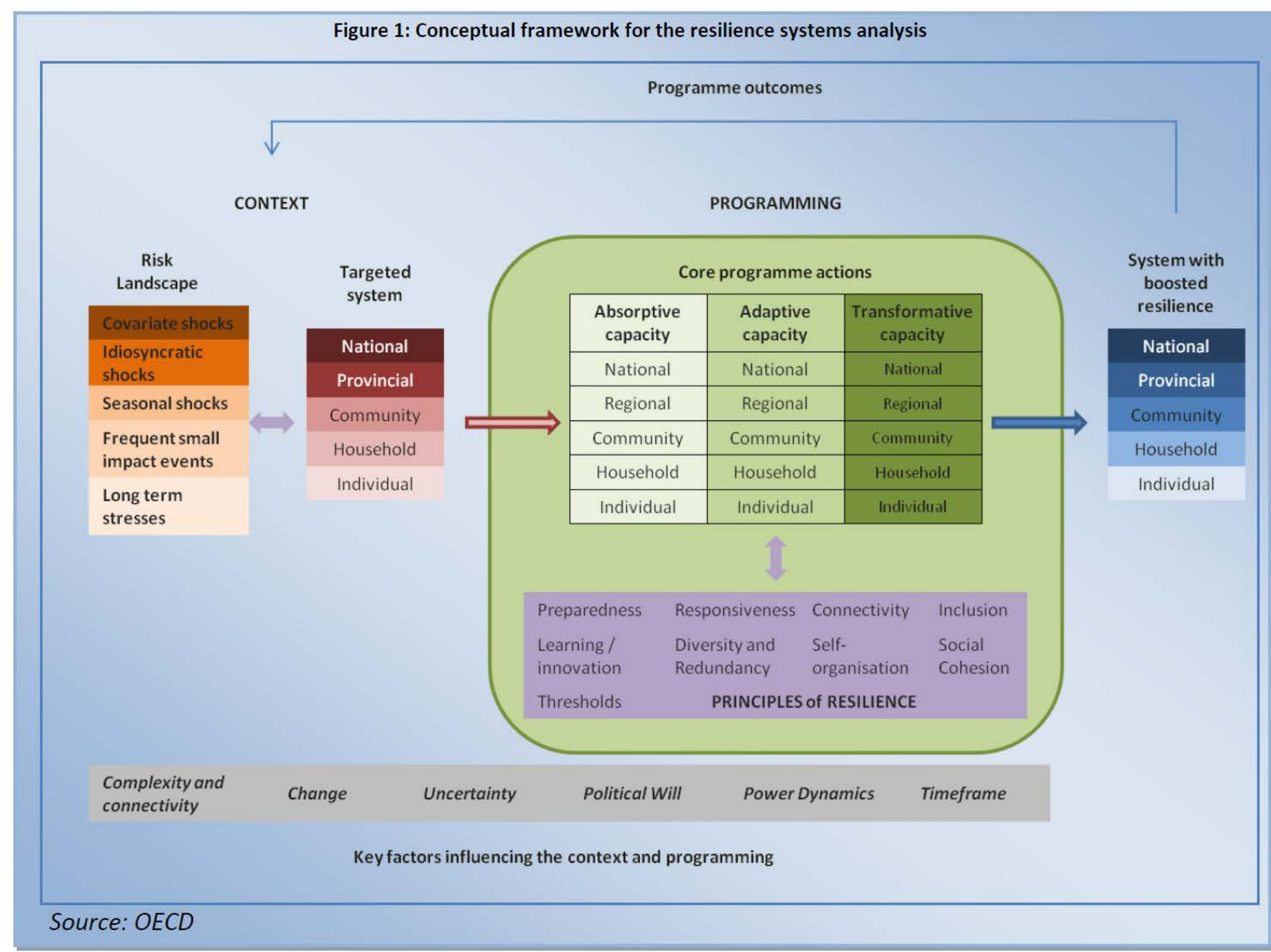




\section{GOVERNING FOR RESILIENCE}

ARE THE GRAND URBAN DESIGNS RESILIENT AND, IF SO, FOR WHOM?
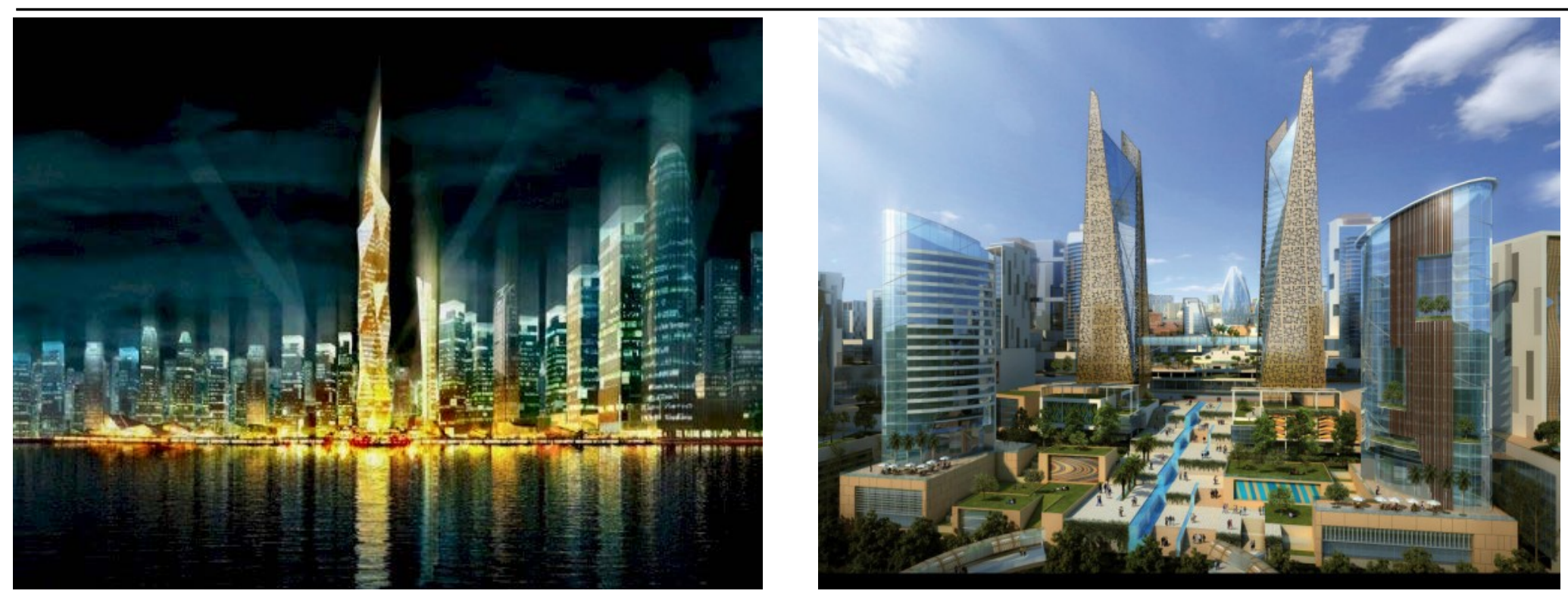


\section{AHMEDABAD, GUJARAT, INDIA}

URBAN REVITALIZATION AND THE SABARMATI RIVER FRONT

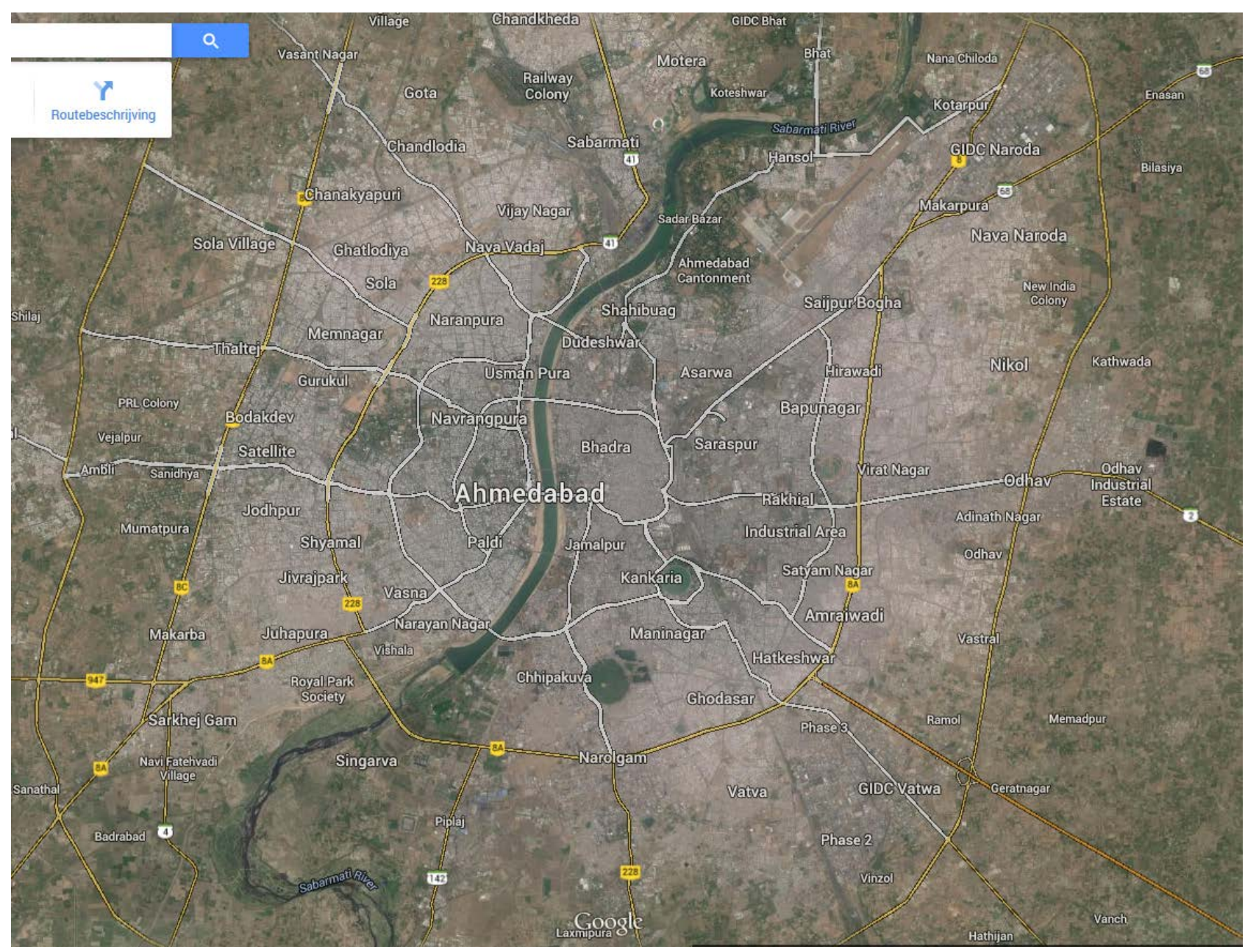




\section{"Modernizing" the River}

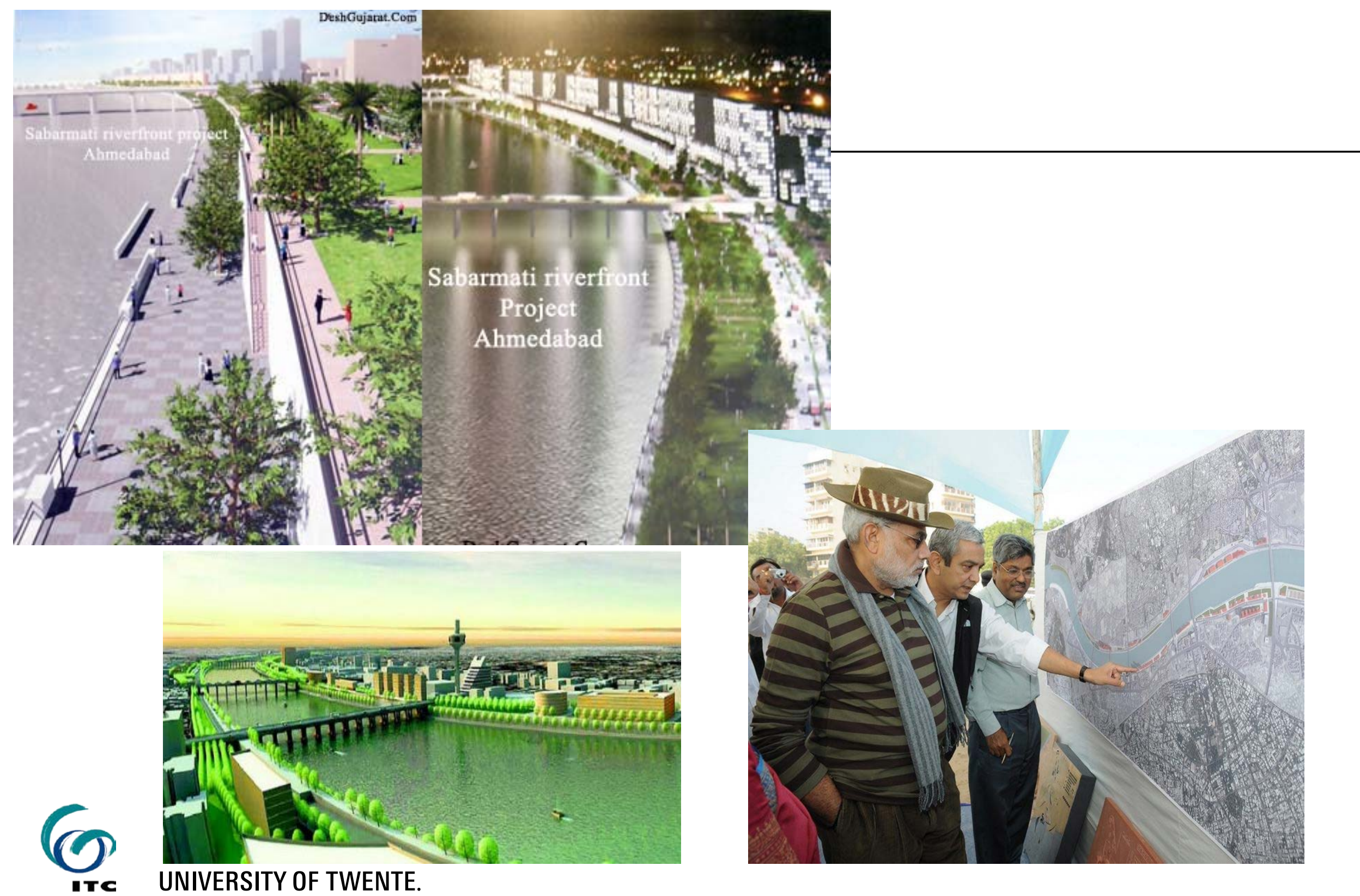




\section{INTERIM RESETTLEMENT SITE}

INTERIM CAN MEAN UP TO 8 YEARS
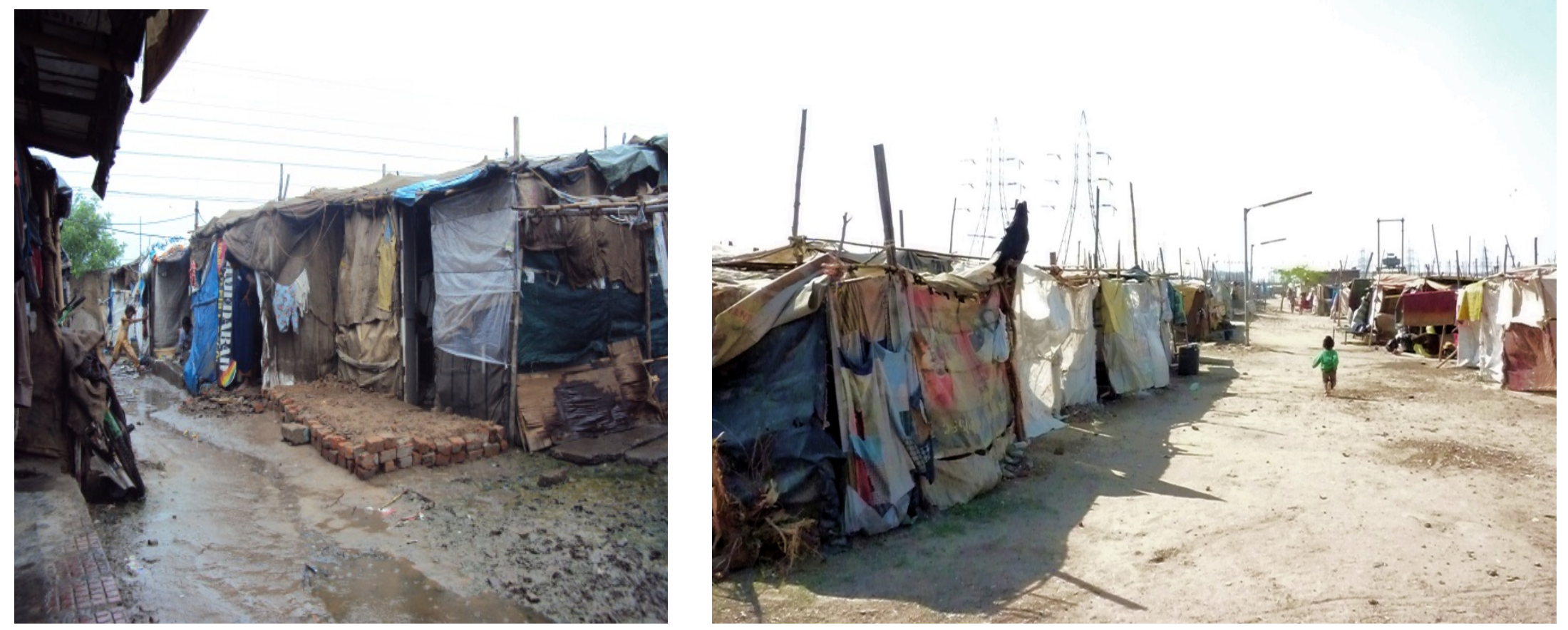

6

UNIVERSITY OF TWENTE. 


\section{DISPLACEMENTS CAUSED BY RESETTLEMENT}

PATEL, SLIUZAS, MATHUR

Major impacts on livelihoods and impoverishment:

- Increased travel distances \& costs for work, schools, health services

- Loss of jobs

- Sense of despair and uncertainty

- Marginalization

- Social disarticulation

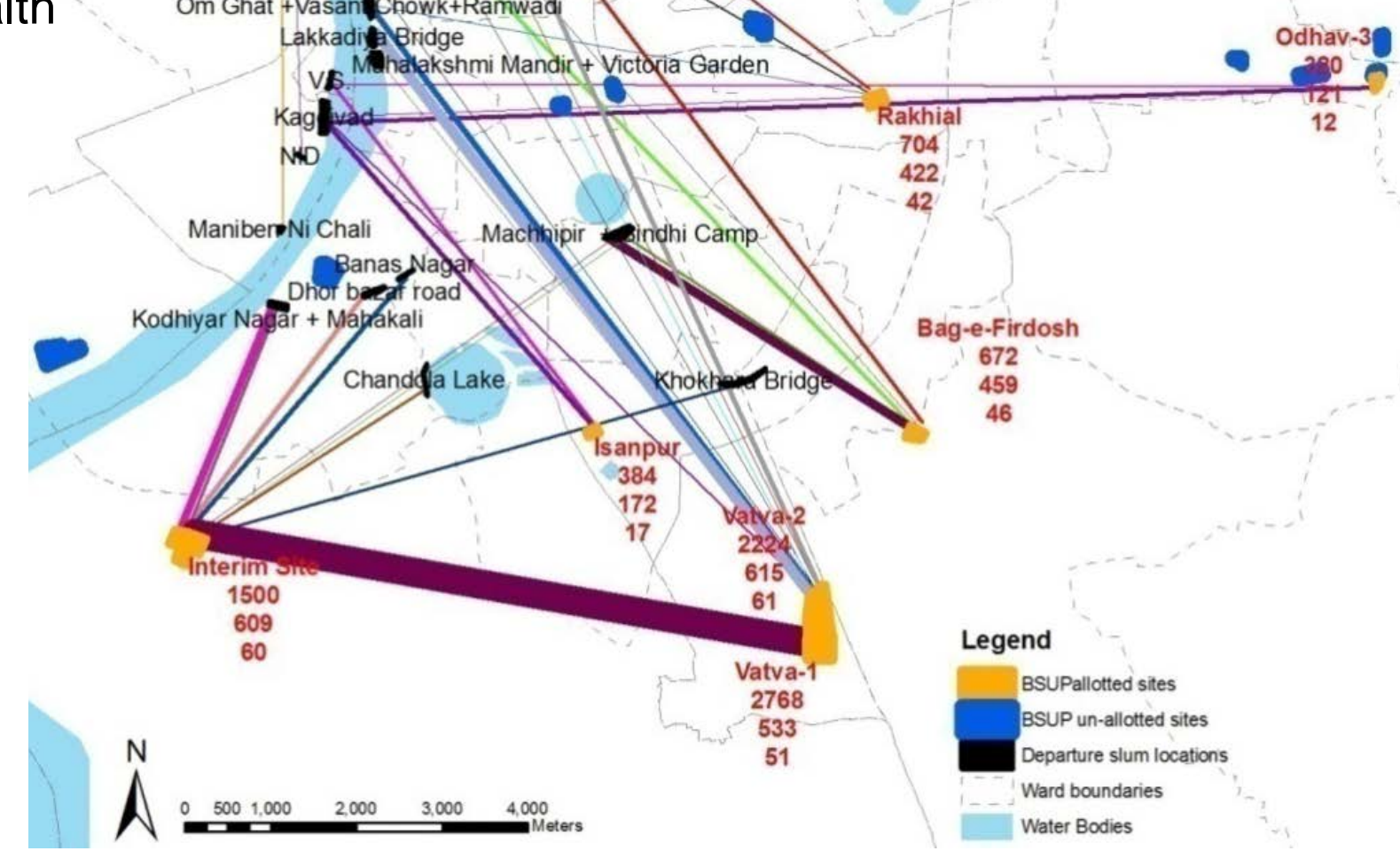




\section{KAMPALA PHYSICAL DEVELOPMENT PLAN}

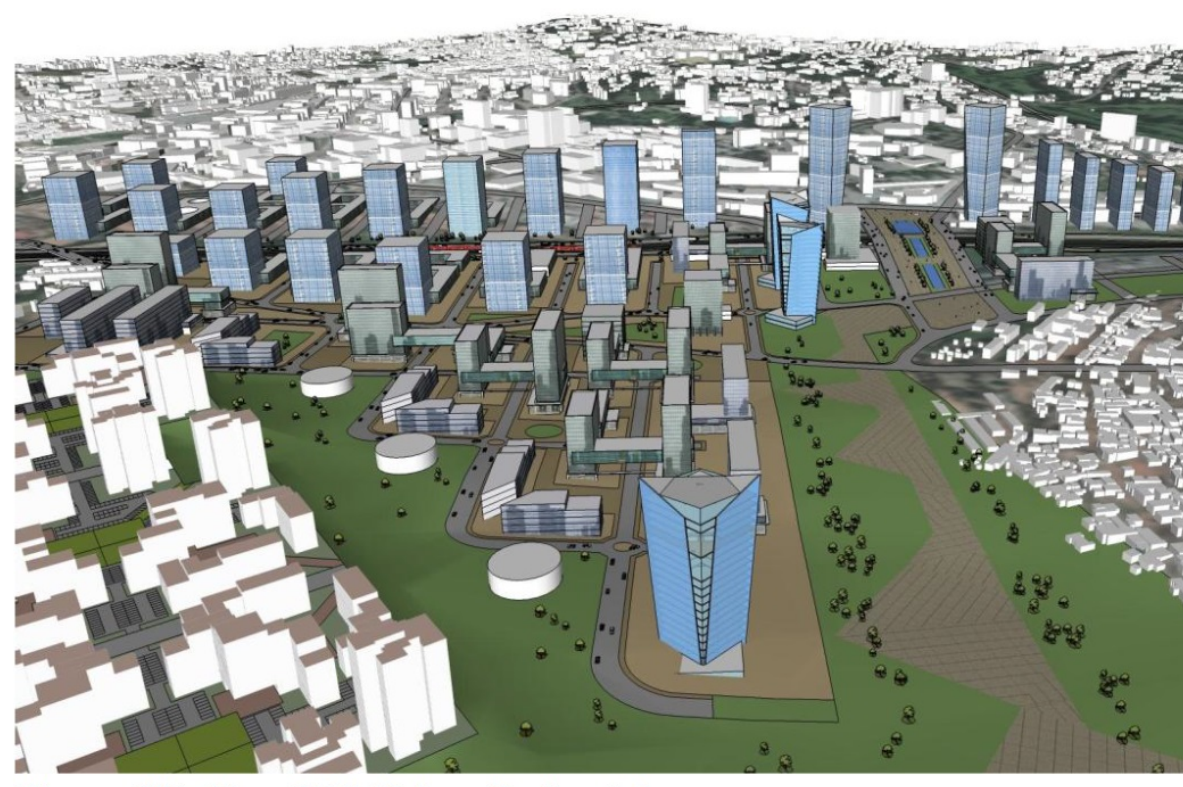

Figure 106: New CBD Urban Design Scheme

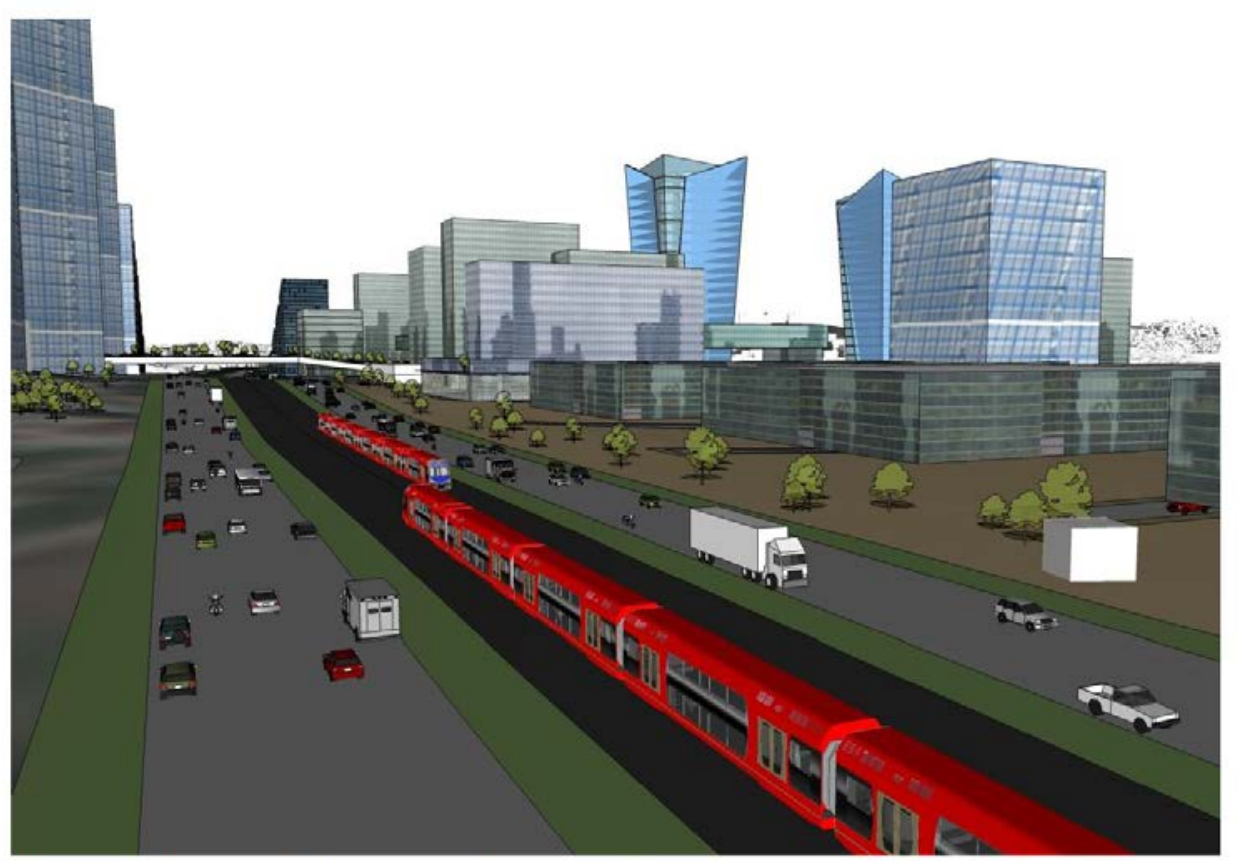

Figure 107: New CBD Urban Design Scheme perspective

HOW DOES IT RELATE TO GROUND REALITIES AND PERSPECTIVES

(6) UNIVERSITY OF TWENTE. 


\section{KAMPALA PHYSICAL DEVELOPMENT PLAN}

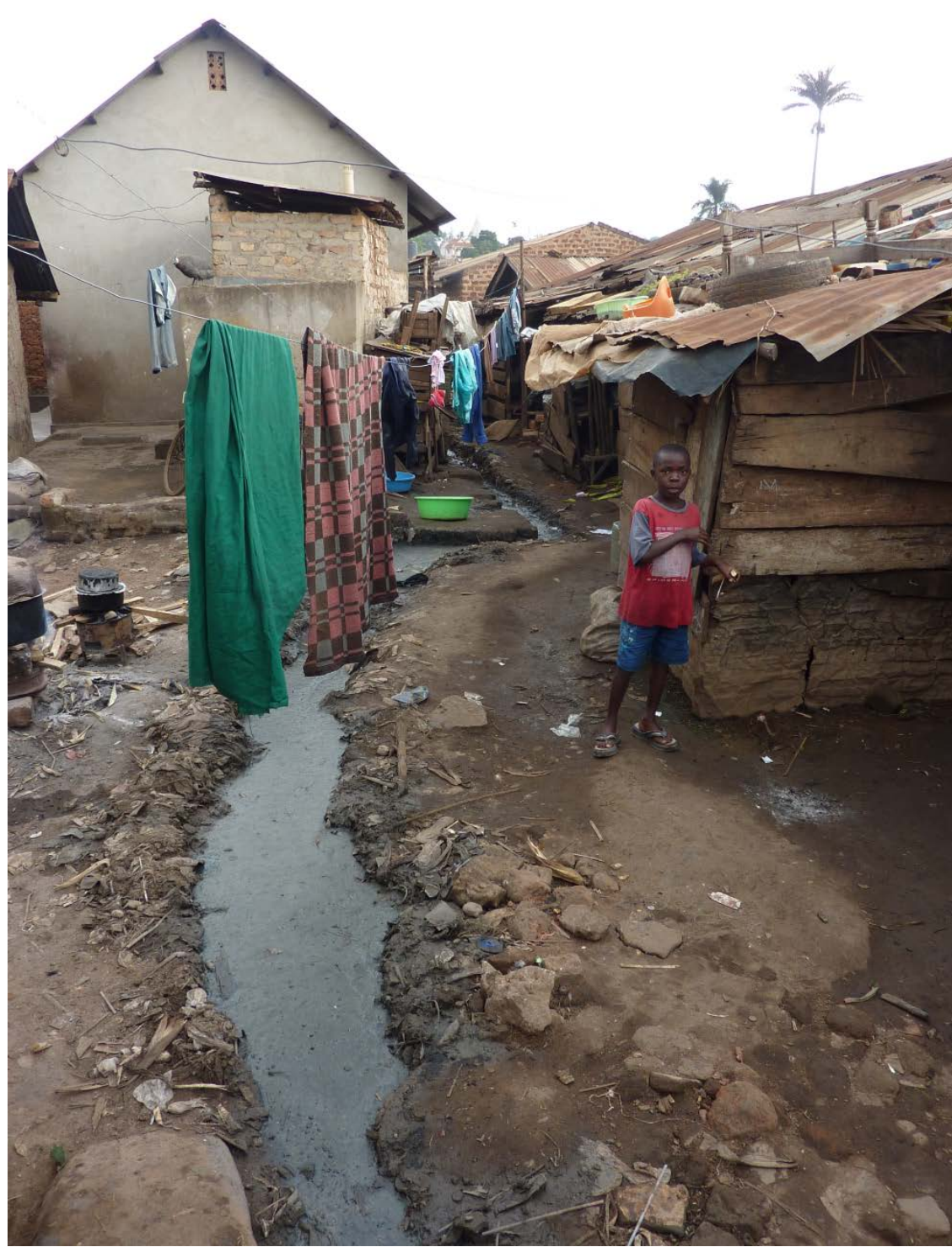

(6) 


\section{SO CAN WE JUST DO RESILIENCE?}

- Doubtful: underlying the quest for resilience are many wicked questions and policy intricacies

- Just as good governance does not just happen so resilience cannot be simply done.

- In governing for resilience more than cursory attention is needed for social equity - fruits of economic development are not equitably distributed nor are the risks and shocks.

- Difficult debates on sharing the pains and the gains are therefore required.

- As recent events related to earthquakes in Groningen show the governability of resilience is not a trivial concern. 


\section{REFERENCES}

- Davoudi, S., Shaw, K., Haider, L. J., Quinlan, A. E., Peterson, G. D., Wilkinson, C., ... Porter, L. (2012). Urban Resilience: What Does it Mean in Planning. Planning Theory \& Practice, 13(2), 299-333.

doi:10.1080/14649357.2012.677124

- Kooiman, J. (2003). Governing as governance. London: Sage Publications.

- Kooiman, J., Bavink, M., Chuenpagdee, R., Mahon, R., \& Pullin, R. (2008). Interactive Governance and Governability: An Introduction. Journal of Transdisciplinary Environmental Studies, 7(1), 1-11. Retrieved from http://dare.uva.nl/document/2/59200

- Kooiman, J. (2008). Exploring the Concept of Governability. Journal of Comparative Policy Analysis: Research and Practice, 10(2), 171-190. doi:10.1080/13876980802028107

- OECD (2014) Guidelines for resilience systems analysis, OECD Publishing. www.oecd.org/publishing/corrigenda

- Rakodi, C. (2003). Politics and performance: the implications of emerging governance arrangements for urban management approaches and information systems. Habitat International, 27(4), 523-547. 


\section{UNIVERSITY OF TWENTE.}

\section{THANK YOU FOR YOUR ATTENTION}
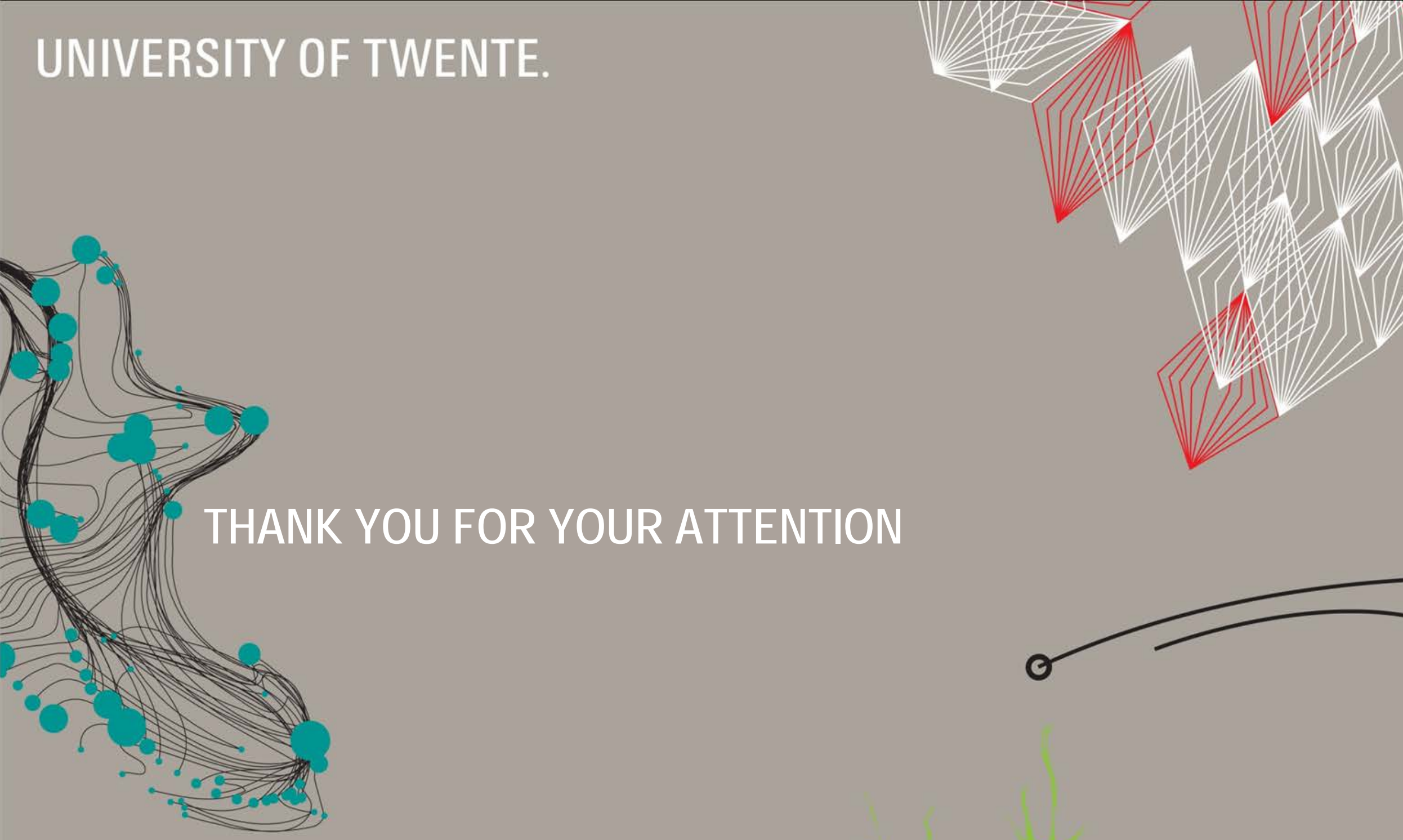